\title{
Politik Hukum Kelembagaan Pengelolaan Zakat Dalam UU No. 21 Tahun 2008 Dan UU No. 23 Tahun 2011
}

\author{
P. Adiyes Putra \\ STAI Diniyah Pekanbaru \\ Jl. KH. Ahmad Dahlan Pekanbaru \\ adiyes.putra123@gmail.com \\ Nurnasrina \\ UIN Suska Riau \\ Jl. HR. Soebrantas Pekanbaru \\ nurnasrina@uin-suska.ac.id
}

\section{Abstrak}

Proses menjadikan RUU perbankan syariah dan RUU pengelolaan zakat menjadi UU yang sah dan legal melewati proses yang panjang. Dalam prosesnya terdapat tarik menarik antara yang mendukung pembentukan undang-undang dengan mereka yang tidak sepakat masalah perbankan syariah dan pengelolaan zakat diatur secara formal dalam bentuk undangundang. Memang harus diakui pembentukan undang-undang dipengaruhi oleh tingkat perkembangan masyarakat, tingkat ekonomi, budaya, ilmu pengetahuan dan teknologi, serta kepercayaan agama dalam sebuah masyarakat. Dari 10 fraksi yang ada di DPR RI, 9 fraksi menyatakan persetujuannya RUU perbankan syariah dan RUU pengelolaan zakat di sahkan menjadi UU, dan ada 1 fraksi yang menolaknya yakni F-PDS. Meskipun ada penolakan dari 1 fraksi, namun akhirnya DPR dan Presiden mengesahkan UU perbankan syariah dengan menetapkan UU No. 21 Tahun 2008 tentang Perbankan Syariah pada tanggal 17 Juni 2008 dan pengundangannya oleh Presiden 
J-Al-Mutharahah : Vol. 17 No. 1 Januari-Juni 2020

pada tanggal 16 Juli 2008. Berikutnya pemuka Islam dan pemerhati zakat mendesak pemerintah untuk segera melakukan amandemen terhadap UU No. 38 Tahun 1999. Atas desakan itu kemudian dan DPR dan pemerintah mensahkan UU No. 23 Tahun 2011 tentang Pengelolaan Zakat sebagai pengganti UU No. 38 Tahun 1999.

\section{Abstract}

The process of making the Draft Law on Islamic banking and the Draft Management Act on zakat becoming a law that is legal and legal goes through a long process. In the process there was a tug of war between those who supported the formation of the law and those who disagreed with the issue of Islamic banking and the management of zakat formally regulated in the form of laws. It must be recognized that the formation of laws is influenced by the level of community development, the level of the economy, culture, science and technology, and religious beliefs in a society. Of the 10 factions in the legislature, 9 factions stated their approval of the Draft Law on Sharia banking and the Draft Management Act on zakat being ratified into law, and there was one faction that rejected it namely the F-PDS. Although there was a rejection from 1 faction, the legislative and the President finally passed the Sharia banking Act by enacting Law Number 21 the Year 2008 on Sharia Banking on June 17, 2008, and its promulgation by the President on July 16, 2008. Next, Islamic leaders and observers zakat urge the government to immediately amend Law No. 38 of 1999. At the insistence of that later and the legislature and the government ratified Law Number 23 of 2011 concerning Management of Zakat in place of Law Number 38 of 1999.

\section{Kata kunci: kelembagaan zakat, perbankan syariah, politik hukum}

Keywords: zakat institution, sharia banking, legal politics 


\section{A. PENDAHULUAN}

Pengesahan Undang-undang Nomor 21 Tahun 2008 tentang Perbankan Syariah (berikutnya ditulis UU No. 21 Tahun 2008) dan Undang-undang Nomor 23 Tahun 2011 tentang Pengelolaan Zakat (berikutnya ditulis UU No. 23 Tahun 2011) melewati jalan panjang dan berliku. Cita-cita umat Islam memiliki payung hukum terhadap pelaknaan perbankan syariah telah dimulai sejak zaman orde baru. Berbagai lobi dan pendekatan dilakukan kepada pemerintah orde baru pada masa itu, tapi belum menuai hasil sesuai yang diharapkan. Usaha itu dilanjutkan ketika zaman reformasi ketika DPR dan Presiden Susilo Bambang Yudhoyono menandatangani pengesahan UU No. 21 Tahun 2008 tentang Perbankan Syariah.

Begitu juga yang terjadi pada pengusulan pengaturan undang-undang pengelolaan zakat, jalan panjang dan berliku juga harus dilewati. Bahkan pengusulan pengaturan tentang penelolaan zakat ini jauh lebih lama ketimbang undang-undang perbankan syariah. Undang-undang pengelolaan zakat telah usulkan untuk diatur dalam bentuk undang-undang sejak masa penjajahan, zaman orde lama, zaman orde baru dan berlanjut zaman reformasi. Pada masa reformasi tepatnya ketika Presiden BJ. Habibie memerintah barulah pengaturan zakat diatur lewat undang-undang sendiri. Pengaturan itu ditandai dengan ditetapkanlah UU No. 38 Tahun 1999 tentang Pengelolaan Zakat. Disahkannya UU pengelolaan zakat ini membawa angin segar terhadap upaya pengelolaan zakat di bawah payung hukum yang formal. Meskipun demikian pengesahan UU pengelolaan zakat ini menuai kritikan-kritikan dan mengusulkan agar dilakukan revisi terhadap UU tersebut. Kritikan-kritikan terus diupayakan sampai akhirnya Presiden Susilo Bambang Yudhoyono bersama dengan DPR mengesahkan berlakukanya UU No. 23 Tahun 2011 
J-Al-Mutharahah : Vol. 17 No. 1 Januari-Juni 2020

tentang Pengelolaan Zakat, sebagai pengganti UU No. 38 Tahun 1999.

Pengesahan UU No. 21 Tahun 2008 tantang Perbankan Syariah dan UU No. 23 Tahun 2011 tentang Pengelolaan Zakat di atas melewati proses yang alot di legislatif. Kealotan proses pembahasan dan pengesahan yang ada di legislatif ini menarik untuk dikaji, sebagai bentuk rekaman dinamika yang terjadi dari sebuah proses pengesahan undang-undang. Oleh karena itu penulis merasa tertarik untuk menelitinya sebagai upaya perekaman terhadap proses dalam pengesahan undang-undang yang terkait perbankan syariah dan pengelolaan zakat.

\section{B. METODE PENELITIAN}

Dalam penelitian ini jenis penelitian yang dilakukan tergolong pada penelitian hukum normatif. Penelitian jenis ini menurut Soerjono Soekanto dan Sri Mamudji disebut juga dengan penelitian perpustakaan. Disebut penelitian perpustakaan dikarenakan metode atau cara yang dipergunakan di dalam penelitian hukum yang dilakukan dengan cara meneliti bahan yang tersedia pada perpustakaan. ${ }^{1}$ Sedangkan metode penelitiannya menggunakan metode penelitian kualitatif. Metode ini didasarkan atas analisis yang dilakukan terhadap UU No. 21 Tahun 2008 tentang Perbankan Syariah dan UU No. 23 Tahun 2011 tentang Pengelolaan Zakat serta peraturan pemerintah lainnya yang berhubungan dengan kelembagaan pengelolaan zakat.

\section{PEMBAHASAN}

Menurut Moh. Mahfud MD, politik hukum adalah legal policy yang akan atau telah dilaksanakan secara nasional oleh pemerintah yang meliputi; pertama, pembangunan hukum yang

${ }^{1}$ Soerjono Soekanto dan Sri Mamudji, Penelitian Hukum Normatif Suatu Tinjauan Singkat, Jakarta: Raja Grafindo Persada, cet. Ke-11, hlm. 13-14 
berintikan perbuatan dan pembaharuan terhadap materimateri hukum agar dapat sesuai dengan kebutuhan; kedua, pelaksanaan ketentuan hukum yang telah ada termasuk penegasan fungsi-fungsi lembaga dan pembinaan para penegak hukum. ${ }^{2}$ Lebih lanjut Mahfud MD menjelaskan legal policy memberikan landasan terhadap proses pembentukan hukum yang lebih sesuai, situasi dan kondisi, kultur serta nilai yang berkembang di masyarakat dengan memperhatikan kebutuhan masyarakat terhadap hukum itu sendiri. ${ }^{3}$

Bellfroid mendefenisikan rechtpolitic yaitu proses pembentukan hukum positif dari hukum yang akan dan harus ditetapkan untuk memenuhi kebutuhan perubahan dalam kehidupan masyarakat. Sunaryati Hartono juga mengemukakan politik hukum sebagai sebuah alat atau sarana dan langkah yang dapat digunakan oleh pemerintah untuk menciptakan sistem hukum nasional yang dikehendaki dan dengan sistem hukum itu akan diwujudkan cita-cita bangsa Indonesia. ${ }^{4}$ Berdasarkan pengertian politik hukum yang dijelaskan di atas dapat dipahami bahwa politik hukum merupakan proses pembentukan hukum yang dilandasi kesesuaian kondisi masyarakat dengan memperhatikan kebutuhan masyarakat terhadap hukum tersebut.

Berangkat dari pengertian di atas, kajian politik hukum yang menjadi pembahasan dalam penelitian ini adalah politik hukum yang terkait dengan kelembagaan pengelolaan zakat pada perbankan syariah. Politik hukum pada kelembagaan pengelolaan zakat akan membahas proses-proses yang terjadi

hlm. 1-2

${ }^{2}$ Moh. Mahfud MD., Politik Hukum di Indonesia, Jakarta: LP3ES, 1998, 2009, hlm. 9

${ }^{3}$ Moh. Mahfud MD., Politik Hukum di Indonesia, Jakarta: Rajawali Press,

${ }^{4}$ Bellfroid dalam Nevi Hasnita, Politik Hukum Ekonomi Syariah di Indonesia, Jurnal Hukum Pidana dan Politik Hukum, Legitimasi, vol. 1, No.2, Januari-Juni 2012 
sebelum UU yang mengatur tentang perbankan syariah dan pengelolaan zakat dinyatakan sebagai payung hukum yang sah dan bersifat mengikat dalam pelaksanaan pengelolaan zakat pada perbankan syariah.

Patut dipahami sebelum UU perbankan syariah dan UU pengelolaan zakat disahkan oleh pemerintah sebagai regulasi, terdapat proses yang panjang dalam menjadikan UU tersebut sebagai UU yang sah dan legal. Dalam prosesnya terdapat tarik menarik antara yang mendukung pembentukan undang-undang dengan mereka yang tidak sepakat masalah perbankan syariah dan pengelolaan zakat diatur secara formal dalam bentuk undang-undang. Memang harus diakui pembentukan undangundang dipengaruhi oleh tingkat perkembangan masyarakat, tingkat ekonomi, budaya, ilmu pengetahuan dan teknologi, serta kepercayaan agama dalam sebuah masyarakat.

Biasanya dukungan terhadap percepatan pengesahan suatu undang-undang akan diberikan secara kuat jika undangundang yang akan disahkan berkaitan dengan basic atau latar belakang baik kesukuan, agama, atau kepentingan terhadap undang-undang tersebut. Sebaliknya ketidaksetujuan atau perlawanan terhadap suatu rancangan undang-undang akan gencar dilakukan jika undang-undang yang diajukan berlawan dengan suku, agama atau kepentingannya. Begitu juga yang terjadi pada pengusulan pengajuan undang-undang yang terkait dengan perbankan yang bebas dari praktek bunga (perbankan syariah) dan pengaturan pengelolaan zakat.

Kedua undang-undang yang menjadi pokok bahasan dalam penelitian ini juga tidak luput dari tarik menarik antara yang mendukung dengan mereka yang menolak. Memang harus diakui pengusulan undang-undang perbankan syariah dan pengelolaan zakat berasal dari umat Islam yang merasa resah dengan perbankan yang ada dan pengelolaan zakat yang belum terkelola secara baik dan profesional. Berikut tinjauan politik hukum terhadap UU perbankan syariah dan pengelolaan zakat. 
J-Al-Mutharahah : Vol. 17 No. 1 Januari-Juni 2020

\section{Politik Hukum Kelembagaan Zakat dalam UU No. 21 Tahun 2008 tentang Perbankan Syariah}

Sistem perbankan yang ada dijalankan dengan sistem bunga, dan sistem ini menurut kesepakatan seluruh ulama di dunia menyatakan bunga bank haram karena bunga bank adalah riba. Riba adalah tindakan yang diharamkan dengan keras oleh syariat Islam. Karena syariat melakukan pelarangan dengan tegas terhadap segala macam bentuk praktek pembungaan, maka menurut Islam tidaklah boleh seorang muslim melakukan tindakan-tindakan yang diharamkan tersebut.

Berangkat dari hal di ataslah kemudian golongan umat Islam mendorong pemerintah untuk segera mengeluarkan regulasi yang membolehkan dibentuknya lembaga perbankan lain selain perbankan yang telah ada. Atas desakan dari seluruh elemen umat Islam-lah kemudian pemerintah mengeluarkan UU No. 7 Tahun 1992 tentang Perbankan, dimana dalam Pasal 6 huruf M dan Pasal 13 huruf C UU ini menyatakan bahwa salah satu usaha dari bank umum dan bank perkreditan rakyat adalah menyediakan pembiayaan bagi nasabah yang didasarkan kepada prinsip bagi hasil. Pencantuman kata bagi hasil menjadi penanda pemerintah telah mulai membuka diri dengan bank yang menjalankan usahanya berdasarkan prinsip bagi hasil. Pencantuman ini juga mengisyaratkan dibolehkannya bank melakukan kegiatan usaha dual banking system atau dua sistem (bagi hasil dan kredit) dalam satu bank yang sama.

Penetapan UU No. 7 Tahun 1992 tentang Perbankan membuka peluang dibentuknya bank yang menjalankan kegiatan usahanya berdasarkan bagi hasil. Peluang ini dimanfaatkan oleh pemuka Islam untuk mendorong berdirinya bank Islam atau bank syariah. Tepatnya tahun 1992, Bank Mu'amalat Indonesia menyatakan dengan resmi beroperasi sebagai mana bank lainnya. Beroperasinya Bank Mu'amalat 
menjadi penanda dibukanya bank syariah pertama di Indonesia dengan prinsip bagi hasil dan tidak menjalankan sistem bunga.

Enam tahun berselang dilakukan perubahan terhadap UU No. 7 tahun 1992 yang kemudian melahirkan UU No. 10 Tahun 1998 tentang Perbankan. Dalam undang-undang ini semakin memberikan peluang terhadap perkembangan perbankan syariah dengan memungkinkan bank umum untuk melakukan kegiatan usaha yang menggunakan prinsip syariah melalui Unit Usaha Syariah (UUS). Dibolehkannya bank umum membuka unit syariah, mendatangkan kritik dari pemerhati masalah ekonomi Islam. Kritikan didasarkan pada penyatuan kegiatan dan pengelolaan keuangan yang berdasarkan syariah dengan keuangan yang bersumber dari yang haram. Kritikan juga muncul dalam hal belum spesifik dan kurang mengakomodasi karakteristik operasional perbankan syariah, sedangkan pertumbuhan dan volume usaha bank syariah berkembang dengan pesat.

Kritikan-kritikan dari pemerhati ekonomi Islam ini terus disuarakan dan diperjuangkan, sehingga akhirnya pemerintah mengesahkan UU No. 21 Tahun 2008 tentang Perbankan Syariah. Pengesahan UU ini menandakan pengaturan tentang perbankan syariah memasuki babak baru, karena pertama kali dalam sejarah pengaturan masalah perbankan syariah dituangkan dalam bentuk UU yang berdiri sendiri, terpisah dengan pengaturan bank secara umum. Pengesahan UU ini juga menandakan adanya perhatian yang besar dari negara, sehingga merasa perlu diatur berdasarkan undang-undang tersendiri.

Pengesahan UU No. 21 Tahun 2008 tentang Perbankan Syariah ini melewati perjuangan yang panjang. Terdapat tarik menarik dalam proses pengesahannya. Tarik menarik itu telah ada sejak ada keinginan pemerintah menerima masukan dari pemerhati ekonomi Islam, terkait kelemahan dan kekurangan yang terdapat dalam UU Perbankan yang telah ada sebelumnya. Masukan-masukan yang disampaikan dan dorongan yang besar 
dari semua elemen umat Islam, membuat pemerintah menyusun Rancangan Undang-Undang (RUU) tentang Perbankan Syariah.

RUU Perbankan Syariah yang diajukan pemerintah kepada DPR RI beranjak dari kebutuhan pengaturan perbankan syariah dalam bentuk UU perbankan syariah. Komisi XI DPR RI yang menangani masalah perekonomian mengeluarkan pokok-pokok pikiran yang melandasi pengajuan RUU perbankan syariah, yaitu; pertama, RUU tentang Perbankan Syariah merupakan RUU yang menjadi prioritas DPR RI pada masa sidang 20042005. Kedua, bahwa perbankan syariah terbukti memiliki peran yang sangat penting dalam pertumbuhan perekonomian Indonesia yang berkeadilan dan kestabilan perbankan nasional, ketika, bahwa perbanakn syariah memakai prinsip-prinsip syariah harus mendapatkan pengawasan yang lebih khusus sesuai dengan peraturan perundang-undangan agar tidak menimbulkan keragu-raguan bagi masyarakat dalam operasionalnya. Keempat, bahwa untuk memberikan landasan hukum yang kuat kepada seluruh pihak yang terkait dengan perbankan syariah, diperlukanlah UU perbankan syariah. ${ }^{5}$

Pokok-pokok pikiran yang melatar belakangi pengajuan RUU tentang Perbankan Syariah, pembentukan substansi atau materi RUU dilandasi oleh prinsip dan asas syariah. Hal ini dituangkan dalam pasal 2 RUU perbankan syariah, yakni; perbankan syariah dalam melakukan kegiatan usahanya berlandaskan pada prinsip syariah dan kehati-hatian. Prinsip syariah dan kehati-hatian yang dimaksud dalam RUU ini dituangkan dalam penjelasan Pasal 2 RUU perbankan syariah, yaitu kegiatan yang tidak mengandung unsur;

a) Riba, yaitu penambahan pendapatan secara tidak sah (batil) antara lain dalam transaksi pertukaran barang sejenis yang tidak sama kualitas, kuantitas, dan

5 Ahmad Dukhoir, Hukum Zakat; Pengaturan Integrasi Kelembagaan Pengelola Zakat Dengan Fungsi Lembaga Perbankan Syariah. Surabaya: Aswaja Presindo, cet. I, 2015, hlm. 120 
waktu penyerahan (fadhl), atau dalam transaksi pinjaman meminjam yang mempersyaratkan nasabah penerima fasilitas mengembalikan dana yang diterima melebihi pokok pinjaman karena berjalannya waktu (nasi'ah).

b) Maisir, transaksi yang digantungkan kepada sesuatu keadaan yang tidak pasti dan bersifat untunguntungan

c) Gharar, transaksi yang objeknya tidak jelas, tidak dimiliki, tidak diketahui keberadaannya, atau tidak dapat diserahkan pada saat transaksi dilakukan kecuali diatur dalam syariah

d) Haram, transaksi yang objeknya dilarang dalam syariah, atau

e) Zalim, transaksi yang menimbulkan ketidakadilan bagi pihak lainnya

f) Sedangkan penjelasan tentang prinsip kehati-hatian adalah pedoman pengelolaan bank yang wajib dianut guna mewujudkan perbankan yang sehat, kuat, dan efisien sesuai dengan ketentuan peraturan perundang-undangan. ${ }^{6}$

Berikutnya tujuan yang hendak dicapai dari RUU Perbankan Syariah adalah menunjang pelaksanaan pembangunan nasional dalam rangka meningkatkan keadilan, dan kesejahteraan rakyat. Sedangkan fungsi bank syariah yang tuliskan dalam RUU itu adalah Bank Syariah dan UUS wajib menjalankan fungsi penghimpunan dan menyalurkan dana masyarakat serta fungsi sosial dalam bentuk lembaga bait almal, yaitu menerima dana yang berasal dari zakat, infak, sedekah, wakaf, hibah atau dana sosial lainnya dan

${ }^{6}$ Penjelasan Pasal 2 RUU tentang Perbankan Syariah 
menyalurkannya kepada yang berhak dalam bentuk santunan dan atau pinjaman kebajikan (al qardh). ${ }^{7}$

Pencantuman kata "serta" dalam fungsi-fungsi yang dijalankan bank syariah pada RUU perbankan syariah menjadikan setiap bank syariah diwajibkan untuk menjalankan fungsi sosial sebagaimana fungsi penghimpunan dan penyaluran dana masyarakat. Artinya dalam RUU ini fungsi intermediasi bank syariah bertambah satu lagi dengan fungsi sosial. Selain mengenai fungsi bank syariah, masih ada poin lain yang menjadi sorotan dari anggota DPR RI ketika RUU perbankan syariah dibahas pada sidang-sidang komisi DPR.

Sewaktu pembahasan RUU perbankan syariah dilakukan oleh DPR, beberapa fraksi memberikan pandangannya terhadap RUU perbankan syariah dapat memberikan kontribusi dalam perekonomian nasional. Dari 10 fraksi yang ada di DPR, satu diantaranya yakni Fraksi Partai Damai Sejahtera (F-PDS) menolak RUU perbankan syariah disahkan dengan alasan bahwa perbankan syariah tidak sesuai dengan hukum dasar Pancasila dan UUD 1945. Mengenai pandangan fraksi-fraksi DPR tentang RUU perbankan syariah, dapat dijelaskan lebih lanjut seperti berikut;

Fraksi Partai Amanat Nasional (F-PAN) DPR RI lewat juru bicaranya Nurul Falah mengemukakan bahwa pada saat ini perbankan syariah telah memberikan kontribusi yang signifikan dalam upaya menumbuh kembangkan sistem ekonomi yang berlandaskan pada nilai keadilan. Nilai keadilan yang jalankan bank syariah terlihat dari upaya menggerakan sektor usaha menengah, kecil dan mikro sebagai fokus bisnis penyaluran pembiayaannya. Selain itu F-PAN juga berpendapat dengan dikembangkannya perbankan yang berlandaskan syariah diharapkan mobilisasi dana dan potensi ekonomi masyarakat muslim dapat dioptimalkan yang pada gilirannya dapat

${ }^{7}$ Ahmad Dukhoir, Hukum Zakat,... hlm. 127 
mendorong pertumbuhan ekonomi. Oleh karena itu F-PAN menyambut baik usul inisiatif Komisi XI DPR RI yang mengajukan RUU tentang perbankan syariah. Berikutnya F-PAN memberikan catatan terhadap RUU perbankan syariah, diantaranya;

a) Perkembangan arus lalu lintas uang dan modal semakin terbuka sejalan dengan derasnya arus globalisasi, termasuk minat investor asing dalam jasa-jasa keuangan dan perbankan. Untuk itu diperlukan perhatian dalam pasal-pasal yang berkenaan dengan kepentingan masyarakat luas dan pelaksanaan pembangunan nasional. F-PAN berpendapat RUU perbankan syariah harus tetap diupayakan dalam rangka mengejar pertumbuhan ekonomi dan pemerataan hasil-hasilnya, stabilitas nasional kearah peningkatan taraf hidup rakyat Indonesia.

b) Pengaturan perbankan syariah berdasarkan prinsip syariah saat ini masih didasarkan pada Peraturan Bank Indonesia (PBI) yang dapat dengan mudah dirubah, sehingga dapat menimbulkan ketidak pastian hukum bagi para pelaku perbankan. Hal ini akan berdampak turunya stabilitas sektor perbankan syariah, oleh karena itu RUU perbankan syariah harus dapat memberikan kepastian hukum.

c) Selama ini pengawasan pelaksanaan prinsip syariah belum optimal dilakukan yang tentunya dapat menimbulkan celah penyimpangan terhadap pelakupelaku jasa perbankan, dengan demikian dapat menimbulkan keraguan masyarakat akan praktek perbankan syariah. Oleh karena harus ada mekanisme pengawasan yang lebih khusus sesuai dengan peraturan perundang-undangan agar tidak 
J-Al-Mutharahah : Vol. 17 No. 1 Januari-Juni 2020

menimbulkan keraguan masyarakat dalam operasionalnya. ${ }^{8}$

Senada dengan F-PAN, Fraksi Partai Kebangkitan Bangsa (F-PKB) DPR RI lewat juru bicaranya Arsa Suthisna menyatakan bahwa perbankan syariah masih berusia muda dan mempunyai kelemahan terutama pada keterbatasan kualitas dan kuantitas sumber daya manusia. Bank syariah harus mempersiapkan sumber daya yang mumpuni dengan integritas, moralitas, dan komitmen yang tinggi. Selanjutnya F-PKB meminta agar dilakukan sosialiasasi perbankan syariah, karena pemahaman masyarakat masih sangat rendah terhadap produk dan perbedaannya dengan bank konvensional. Berikutnya F-PKB menyambut baik RUU perbankan syariah, mudah-mudahan dapat menjadi payung hukum bagi perbankan syariah yang sudah mulai tumbuh dan berkembang di negeri ini. Namun terhadap materi yang ada dalam RUU perbankan syariah masih terdapat kelemahan dan perlu penyempurnaan. Kelemahan misalnya terdapat pada mekanisme perlindungan keuangan nasabah dari manipulasi keuangan dalam sistem bagi hasil, jaminan adanya akses bagi para nasabah yang ingin mengetahui kemajuan kegiatan usaha yang dijalankan oleh perbankan, termasuk laba rugi dari kegiatan usaha dan bagaimana manajemen risiko keuangannya ketika usaha yang dijalankan merugi, sehingga tidak mengganggu dana pokok yang disetorkan oleh nasabah. ${ }^{9}$

Fraksi Partai Demokrasi Indonesia Perjuangan (F-PDIP) yang disampaikan juru bicaranya Tukijo mengemukakan perbankan syariah mengalami peningkatan yang pesat dan mendapat respon yang positif dari pihak industri jasa perbankan. Untuk itu perbankan syariah tidak boleh berdiri

${ }^{8}$ Djawahir Hejazziey, Politik Hukum... hlm. 241 dan lihat juga Ahmad Dukhoir, Hukum Zakat... hlm.136-137

${ }^{9}$ Djawahir Hejazziey, Politik Hukum... hlm. 241 dan lihat juga Ahmad Dukhoir, Hukum Zakat... hlm.138 
secara eksklusif membatasi diri dari pihak yang akan menggunakan jasa perbankan syariah, melainkan juga harus terbuka untuk kepentingan semua lapisan masyarakat. Menurut F-PDIP RUU perbankan syariah adalah suatu hal yang sangat penting untuk ditindak lanjuti dalam proses pembuatan undangundang, sehingga ada beberapa hal yang perlu untuk diperhatikan; pertama, alasan adanya pembuatan RUU tentang perbankan syariah dalam rangka memasuki perkembangan perdagangan dalam negeri dan internasional, bank wajib menjamin dana masyarakat dan pengaturan serta pengawasan bank. Kedua, masalah kerahasiaan bank perlu diadakan batasanbatasan yang jelas dan rinci sehingga tidak mengganggu industri perbankan. Ketiga, kekhususan perbankan syariah dalam RUU ini hendaknya tidak berbenturan dengan undang-undang lainnya. Keempat, dalam penambahan, pengurangan dan penyempurnaan hendaknya lebih ditingkatkan peran perbankan dalam pembiayaan pada sektor ekonomi kerakyatan. Kelima, perubahan baik penambahan atau pengurangan pasal dalam RUU perbankan syariah ini agar melibatkan instansi/lembaga lain sehingga RUU ini dapat menampung pasal dan ayat lain di luar undang-undang dibidang keuangan dan jasa keuangan. ${ }^{10}$

Fraksi Partai Golkar (F-PG) menyampaikan pandangannya terhadap RUU perbankan syariah seperti yang dijelaskan oleh Harry Azhar Azis. Ia menyampaikan bahwa orientasi dalam UU perbakan syariah adalah pada stabilitas sistem dengan mengadopsi 25 Based Core Principles for Effective Banking Supervision terutama terkait perizinan, prudential, kewajiban pengelolaan risiko, pembinaan dan pengawasan, dan jejaring pengaman sistem perbankan syariah. F-PG juga menilai dengan adanya prinsip ini maka RUU perbankan syariah akan memiliki

${ }^{10}$ Djawahir Hejazziey, Politik Hukum... hlm. 241 dan lihat juga Ahmad Dukhoir, Hukum Zakat... hlm.134 
aspek kepatuhan syariah, perlindungan konsumen, kenyamanan iklim investasi, dan kepastian usaha serta stabilitas perbankan secara keseluruhan. Menurut F-PG, keberadaan perbankan syariah secara filosofis, yuridis, sosiologis dan historis memiliki karakteristik yang berbeda dengan bank pada umumnya, sehingga aturan hukum yang akan dibentuk untuk memperkuat kedudukan perbankan syariah harus mempunyai karakteristik tersendiri pula. Karakteristik yang akan dibentuk harus disesuaikan dengan kemandirian aturan dan kemandirian struktural. Pendapat F-PG perbankan syariah sebagai wujud perkembangan ekonomi syariah harus seirama dan sekata dengan pelaksanaan prinsip dasar falsafah bangsa Indonesia yang berketuhanan yang Maha Esa. ${ }^{11}$

Fraksi Partai Persatuan Pembangunan (F-PPP) juga mengemukakan pandangan fraksinya seperti yang disampaikan oleh Sofyan Usman. Keberadaan UU perbankan syariah sudah sangat mendesak dan telah lama dinanti-nanti sebagai payung hukum beroperasinya perbankan syariah. Perbankan syariah di Indonesia sudah cukup lama beroperasi dan mengalami perkembangan yang sangat pesat. Perkembangan yang pesat menunjukkan adanya minat berbagai kalangan dalam menggunakan jasa perbankan syariah, sehingga harus dijawab dengan memberikan ruang yang semakin terbuka dan berkembang. 12

Berikutnya Fraksi Partai Demokrat (F-PD) lewat juru bicaranya Tata Zainul Muttaqien mengemukakan bahwa perbankan syariah merupakan salah satu wujud untuk memulihkan perekonomian nasional melalui investasi dalam dunia perbankan syariah khususnya investasi dari luar negeri terutama negara-negara timur tengah, oleh karena itu perlu

${ }^{11}$ Djawahir Hejazziey, Politik Hukum... hlm. 241 dan lihat juga Ahmad Dukhoir, Hukum Zakat... hlm.131

12 Djawahir Hejazziey, Politik Hukum... hlm. 241 
J-Al-Mutharahah : Vol. 17 No. 1 Januari-Juni 2020

pengaturan yang rinci daln lebih jelas tentang perbankan syariah. 13

Dorongan positif terhadap RUU perbankan syariah juga ditunjukan oleh Fraksi Partai Bintang Reformasi (F-PBR), lewat juru bicaranya Zainul Abidin menjelaskan bahwa siapa saja dapat yang memanfaatkan jasa keuangan bank syariah. Ketika krisis moneter melanda Indonesia pada pertengahan 1997, sistem syariah telah memberikan bukti dengan tetap memberikan manfaat bagi banyak kalangan. Ini menjadi salah satu fakta bahwa bank syariah memberikan kontribusi yang signifikan bagi ketahanan dan pertumbuhan perekonomian negara, oleh karena itu F-PBR menyetujui RUU perbankan syariah dibahas menjadi UU. ${ }^{14}$

Seirama dengan pandangan F-PBR, Fraksi Partai Keadilan Sejahtera (F-PKS) yang disampaikan oleh Mustafa Kemal mengemukakan bahwa F-PKS memandang perlunya disusun perangkat UU sebagai landasan hukum yang kuat terhadap perbankan syariah. F-PKS juga berharap dalam pelaksanaan perbankan syariah harus diikuti dengan keberpihakan yang lebih besar dan nyata dalam hal penyaluran dana bagi usaha kecil dan menengah serta kemudahan akses dana bagi UMKM. Keberpihakan tersebut akan mampu menggerakkan sektor riil dan memiliki manfaat yang lebih bagi terciptanya kemakmuran dan kesejahteraan rakyat. 15

Fraksi terakhir yang memberikan dukungan terhadap pengesahan UU perbankan syariah adalah Fraksi Bintang Pelopor Demokrasi (F-BPD). F-BPD memberikan persetujuan terhadap usulan pembahasan RUU perbankan syariah untuk dijadikan sebagai UU perbankan syariah.

13 Djawahir Hejazziey, Politik Hukum... hlm. 242

14 Djawahir Hejazziey, Politik Hukum... hlm. 242 dan lihat juga Ahmad Dukhoir, Hukum Zakat... hlm.141

${ }^{15}$ Djawahir Hejazziey, Politik Hukum... hlm. 242 dan lihat juga Ahmad Dukhoir, Hukum Zakat... hlm.139 
Berbeda dengan pandangan 9 fraksi di atas, Fraksi Partai Damai Sejahtera (F-PDS) menyatakan ketidaksetujuannya terhadap RUU perbankan syariah dijadikan sebagai UU. Pernyataan itu disampaikan dalam pandangan umum fraksi yang dibacakan oleh Retna Rosmita Situmorang. Menurutnya informasi di beberapa negara yang ia ketahui, terbukti bahwa produk perbankan syariah tidak dalam bentuk undang-undang, hanya merupakan turunan dari undang-undanag perbankan yang telah ada, bukan dalam undang-undang khusus. Selanjutnya F-PDS juga mengemukakan setelah melakukan kajian terhadap naskah RUU perbankan syariah serta memperhatikan arti filosofis, maksud dan tujuan yang tersirat maupun yang tidak tersirat dalam arti kata bernegara yang dianut hanya dan agama tertentu, maka F-PDS menyatakan menolak segala upaya yang dilakukan untuk membuat UU dalam hal ini UU Surat Berharga Syariah Negara dan RUU perbankan syariah. Penolakan didasarkan atas pembahasan RUU SBSN dan RUU perbankan syariah yang hanya bersumberkan pada satu agama saja, dan F-PDS menganggap dan meyakini hal tersebut bukan saja mengancam keutuhan NKRI tetapi juga tidak akan membuat negara ini menuju kesejahteraan dan kemajuan. ${ }^{16}$

Memperhatikan pendapat-pendapat yang disampaikan fraksi-fraksi di DPR RI di atas, dapat disimpulkan bahwa 9 dari 10 fraksi yang ada di DPR RI menyatakan dukungannya terhadap pengesahan UU perbankan syariah, dan hanya 1 fraksi yang menyatakan menolak ditetapkan menjadi UU. Meskipun mayoritas fraksi menyetujui pengesahan UU perbankan syariah, tapi masukan-masukan dan perubahan terhadap RUU yang telah diajukan banyak perubahan. Perubahan yang sangat menjadi sorotan adalah terkait fungsi bank syariah. Dalam Pasal 4 ayat 2 UU perbankan syariah yang dalam RUU memuat "Bank Syariah

${ }^{16}$ Djawahir Hejazziey, Politik Hukum... hlm. 243 dan lihat juga Ahmad Dukhoir, Hukum Zakat... hlm.143 
dan UUS wajib menjalankan fungsi penghimpunan dan penyaluran dana masyarakat serta fungsi sosial dalam bentuk lembaga bait al-mal, yaitu menerima dana yang bersumber dari zakat, infak, sedekah, wakaf, hibah, atau dana sosial lainnya dan menyalurkannya kepada yang berhak dalam bentuk santunan dan atau pinjaman kebajikan (al-qardh)".

Rancangan yang dimuat dalam pasal 4 ayat 2 RUU seperti di atas mengalami perubahan mendasar ketika draf ini masuk di meja pemerintah melalui rapat dengar pendapat oleh fraksifraksi dengan Menteri Keuangan, Menteri Agama, Menteri Kesejahteraan Rakyat, dan Menteri Hukum dan HAM sebagai wakil pemerintah. ${ }^{17}$ Perubahan mendasar terkait dengan Pasal 4 ayat 2 tersebut adalah dihapuskannya kata "serta" dan membagi pasal itu menjadi 2 ayat, sehingga pasal 4 itu berbunyi: Ayat 1 : Bank Syariah dan UUS wajib menjalankan fungsi menghimpun dan menyalurkan dana masyarakat.

Ayat 2 : Bank Syariah dan UUS dapat menjalankan fungsi sosial dalam bentuk lembaga bait al-mal, yaitu menerima dana yang bersumber dari zakat, infak, sedekah, wakaf tunai, hibah, atau dana sosial lainnya dan menyalurkannya kepada yang berhak dalam bentuk santunan dan atau pinjaman kebajikan (al-qardh).

Penghapusan kata "serta" dalam Pasal 4 di atas secara norma merupakan perubahan yang sangat signifikan terhadap politik hukum fungsi perbankan syariah. Fungsi bank syariah yang berdasarkan RUU menjadikan kewajiban bagi bank syariah untuk menjalankan fungsi sosial sebagaimana fungsi menghimpun dan menyalurkan dana, maka setelah perubahan pasal 4 kewajiban itu berpindah menjadi dapat menjalankan.

${ }^{17}$ Rapat tim penyempurnaan RUU perbankan syariah diadakan di Grand Ball Room dan Embassy Room Hotel Savoy Homan, Jalan Asia Afrika Bandung pada Tanggal 30 Juni sampai 2 Juli 2006 
Artinya bank syariah sebagai lembaga intermediasi dalam fungsi sosial menjadi kabur atau hilang sama sekali. Hal ini didasarkan pada terpisahnya fungsi pokok bank syariah sebagai intermediasi dengan fungsi sosial sebagai fungsi yang bersifat anjuran atau tambahan.

Seterusnya dalam tanggapan pemerintah yang disampaikan oleh Menteri Keuangan Sri Mulyani pada tanggal 21 Maret 2007, bahwa RUU perbankan syariah memiliki kelemahan dan perlu untuk disempurnakan. Penyempurnaan dilakukan atas RUU perbankan syariah berdasarkan usulan pemerintah, adapun perubahannya adalah sebagai berikut:

a) Menghapus kata "wakaf tunai" dan membuat ayat tersendiri yang mengatur tentang wakaf.

b) Kata-kata "yang berhak dalam bentuk santunan dan atau pinjaman kebajikan" dirobah menjadi "organisasi pengelola zakat".

c) Menambah penjelasan mengenai "organisasi pengelola zakat".

Atas usulan pemerintah terhadap perubahan Pasal 4 itu, maka naskah RUU perbankan syariah berubah menjadi "Bank Syariah dan UUS dapat menjalankan fungsi sosial dalam bentuk lembaga bait al-mal, yaitu menerima dana yang bersumber dari zakat, infak, sedekah, hibah, atau dana sosial lainnya dan menyalurkannya kepada organisasi pengelola zakat". Organisasi pengelola zakat yang dimaksud seperti yang dijelaskan dalam RUU tersebut adalah Badan Amil Zakat Nasional (BAZNAS), dan Lembaga Amil Zakat (LAZ).

Berdasarkan politik hukum terhadap pengesahan UU perbankan syariah di atas melalui jalan berliku dan panjang, namun akhirnya kemudian DPR dan Presiden mengesahkan UU perbankan syariah dengan menetapkan UU No. 21 Tahun 2008 tentang Perbankan Syariah pada tanggal 17 Juni 2008 dan 
pengundangannya oleh Presiden pada tanggal 16 Juli 2008.18 Meskipun telah disahkan, perubahan-perubahan yang dilakukan lewat politik hukum yang terjadi antara DPR dan pemerintah mendapatkan catatan-catatan tersendiri terutama bagaimana terjadinya tarik menarik dalam pasal 4 ayat 2 . Perubahan dalam pasal ini secara tidak langsung telah melakukan penghambatan secara konstitusi terhadap pengelolaan zakat lewat perbankan syariah. Bank syariah tidak dibiarkan untuk aktif melakukan pengelolaan zakat seperti keaktifannya dalam menghimpun dan menyalurkan dana masyarakat.

2. Politik Hukum Kelembagaan Pengelolaan Zakat dalam UU No. 23 Tahun 2011 tentang Pengelolaan Zakat

Politik hukum yang berliku dan panjang berikutnya juga terjadi pada pengesahan UU No. 23 Tahun 2011 tentang Pengelolaan Zakat. Setelah hampir tiga puluh tahun vakum dan tidak memiliki kepastian hukum, pada awal tahun 1990-an kajian zakat kembali menguat. Pemerintah terus mendapatkan desakan dari pemuka Islam untuk segera membuat aturan hukum formal sebagai landasan pengelolaan zakat. Akhirnya pada tahun 1999 pemerintah mengajukan usulan RUU pengelolaan zakat kepada DPR.

Pengajuan RUU itu didasarkan atas pertimbangan konstitusional bahwa negara menjamin kemerdekaan penduduk untuk beribadah menurut agamanya. Adapun tujuan dari RUU pengelolaan zakat adalah memberikan aturan hukum setingkat undang-undang bagi upaya pengelolaan dan pendayagunaan zakat. Akhirnya RUU ini dapat disahkan menjadi undang-undang pada tanggal 23 September 1999 lewat

18 UU No.21 Tahun 2008 tentang Perbankan Syariah dimuat dalam lembaran Negara Republik Indonesia Tahun 2008 No. 94 dan Tambahan Lembaran Negara No. 4867 
keputusan pengesahan UU No. 38 Tahun 1999 tentang Pengelolaan Zakat. ${ }^{19}$

Lahirnya UU pengelolaan zakat tahun 1999 tentu membawa angin segar bagi semangat pengelolaan zakat di Indonesia. Pengelolaan zakat yang sebelumnya hanya dijadikan sebagai ibadah rutin tanpa kekuatan hukum dalam pelaksanaannya, dan jauh dari kata profesional dalam pengelolaannya, belum mampu mengumpulkan zakat secara masif. Dan diharapkan setelah adanya kekuatan hukum pengelolaan zakat dapat meningkatkan pengelolaan zakat baik dalam penghimpunan dana, penyaluran dan pendayagunaan dana zakat tersebut. Tapi setelah beberapa tahun berjalan, keberadaan UU No. 38 Tahun 1999 tentang Pengelolaan Zakat belum mampu mengatasi permasalahan mengenai zakat, bahkan pengelolaan zakat bagai "benang kusut yang tak terurai". Masyarakat beranggapan terjadi keruwetan dalam pelaksanaan UU karena peraturan pengelolaan zakat tidak memiliki kekuatan untuk memaksa muzakki dalam membayar zakat. Ketiadaan peraturan untuk memaksa muzakki membayar zakat bagi sebagian kalangan yang belum memiliki komitmen moral tentu membuka peluang bagi mereka untuk tidak membayar zakat.

Kelemahan lainnya dari UU No. 38 Tahun 1999 adalah tidak adanya perangkat peraturan teknis dibawahnya yang mengikat berupa peraturan pemerintah (PP). Sehingga ketiadaan peraturan itu membuat implementasi di lapangan menjadi kebingunan dan ketidakpastian dikalangan stakeholder zakat dalam menjalankan pengelolaan zakat. Setelah UU No. 38 Tahun 1999 praktis regulasi yang muncul hanyalah berupa Keputusan Menteri Agama (Permen) No. 581 Tahun 1999 tentang Pelaksanaan UU No. 38 Tahun 1999, Keputusan Dirjend

${ }^{19}$ Mustolih Siradj, Jalan Panjang Legislasi Syariat Zakat di Indonesia; Studi Terhadap Undang-Undang No. 23 Tahun 2011 tentang Pengelolaan Zakat, Jurnal Bimas Islam, Vol. 7 No. 3 Tahun 2014, hlm. 417 
Bimas Islam dan Urusan Haji No. D/291 Tahun 2000 tentang Pedoman teknis Pengelolaan Zakat. ${ }^{20}$

Selain itu UU pengelolaan zakat Tahun 1999 juga memiliki problem mendasar yang dihadapi terutama masalah kesimpang siuran siapa yang harus menjadi lending sector. Ketidakharmonisan komunikasi antara lembaga pengelola zakat baik BAZNAS dan LAZ memunculkan dikotomi diantara keduanya, seakan-akan BAZNAS hanya bekerja dan bertanggung jawab kepada pemerintah dan LAZ bertanggung jawab kepada masyarakat. Masing-masing berjalan sendiri-sendiri, sehingga mengakibatkan ketumpulan dalam strategi memerangi kemiskinan karena berjalan parsial dan minimnya sinergi. Kondisi ini tentunya tidak kondusif sehingga potensi zakat yang begitu besar tidak bisa dikelola secara baik dan profesional. Pengelolaan maupun pendistribusian zakat seakan tidak memiliki arah, masing-masing menjalankan visinya tanpa adanya koordinasi, sehingga baik BAZNAS dan LAZ tidak memiliki data akurat yang terintegrasi baik data muzakki, mustahiq maupun data lainnya.

Hal yang sama juga dirasakan oleh pemerintah pusat dan daerah, pemerintah tidak bisa berbuat lebih banyak selain dari bersifat anjuran dan ajakan kepada muzakki untuk segera membayar zakat. Pemerintah tidak bisa masuk keranah yang lebih tegas semisal mengeluarkan peraturan pemerintah yang mewajibkan kepada muzakki untuk mengeluarkan zakat. Tidak bisanya pemerintah mengeluarkan kewajiban mengeluarkan zakat karena memang secara yuridis formal pemerintah selalu pemegang otoritas kurang berdaya untuk memaksa muzakki membayar zakatnya. Sehingga dengan ketiadaan penegasan dari pemerintah, penghimpunan dana zakat menjadi lembek dan tidak bergairah. Hal ini berbeda jauh ketika Khalifah-khalifah

${ }^{20}$ Mustolih Siradj, Jalan Panjang,... hlm. 419 dan lihat juga Ahmad Dukhoir, Hukum Zakat,... hlm. 150-152 
Islam terdahulu dalam menerapkan penghimpunan zakat. Khalifah Islam mewajibkan kepada seluruh umat Islam yang telah memenuhi ketentuan wajib zakat untuk mengeluarkannya, dan bagi yang tidak mau mengeluarkan zakat akan diperangi oleh khalifah. Ini merupakan bentuk ketegasan pemerintah dalam menjalankan perintah agama, sehingga dengan ketegasan itu bisa terhimpun zakat dalam jumlah yang besar.

Berdasarkan hal di atas, pemuka Islam dan pemerhati zakat mendesak pemerintah untuk segera melakukan amandemen terhadap UU No. 38 Tahun 1999. Atas desakan itu kemudian pemerintah mengajukan RUU pengelolaan zakat yang baru sebagai pengganti UU pengelolaan zakat tahun 1999. Akhirnya setelah melalui proses yang panjang dan diskusi yang alot antara DPR dengan pemerintah, disahkanlah UU No. 23 Tahun 2011 tentang Pengelolaan Zakat. Pengesahan UU No. 23 ini menandakan UU No. 38 Tahun 1999 menjadi tidak berlaku.

Meskipun UU No. 23 Tahun 2011 tentang Pengelolaan Zakat ini telah disahkan, tapi masih mendatangkan kritik dari penggiat zakat. Menurut Yahya Harahap (mantan Hakim Agung Mahkamah Agung RI), ia mengemukakan mustahil menciptakan produk undang-undang yang sempurna, sebab bagaimanapun bagus dan sempurnanya sebuah undang-undang, pasti akan berhadapan dengan seribu satu macam masalah yang sebelumnya tidak diperkirakan dan tidak diprediksi pada saat undang-undang itu dirumuskan. ${ }^{21}$ Begitu juga yang terjadi pada UU No. 23 Tahun 2011, kritikan-kritikan yang disampaikan tidak mengubah kekuatan UU yang telah disahkan kecuali ada Keputusan dari Mahkamah Konstitusi yang membatalkan atau mengubah UU tersebut.

Sebagai upaya perubahan terhadap UU No. 23 Tahun 2011 tentang Pengelolaan Zakat itu, penggiat zakat yang dimotori oleh 2009, hlm. 27

${ }^{21}$ Yahya Harahap, Hukum Perseroan Terbatas, Jakarta: Sinar Grafiti, 
lembaga-lembaga zakat dan perorangan mengajukan permohonan uji materi (judicial review) terhadap UU Pengelolaan Zakat kepada Mahkamah Konstitusi (MK). ${ }^{22}$ Menurut pemohon dengan diundangkannya UU No. 23 Tahun 2011 akan membuat pengelola zakat khususnya yang dilakukan oleh masyarakat sipil baik secara kelembagaan melalui LAZ yang berbadan hukum maupun amil zakat tradisional yang dikelola secara perorangan akan berpotensi mengalami kemunduran. Selain itu juga akan mengalami kerugian konstitusional, marginalisasi, subordinasi, dan ketidaknyamanan dalam menjalankan aktifitas selaku LAZ. Mereka juga berada dalam bayang-bayang ketakutan karena berpotensi mengalami diskriminasi dan kriminalisasi. ${ }^{23}$ Atas dasar itu kemudian lembaga zakat dan perorangan mengajukan uji materi UU pengelolaan zakat tersebut.

Berdasarkan uji materi yang diajukan, kemudian Mahkamah Konstitusi melakukan persidangan-persidangan yang pada akhirnya memutuskan hanya mengabulkan sebagian pasal yang dimohonkan oleh para pemohon yakni Pasal 18 ayat 2 poin a, b, dan d tentang syarat pembentukan Lembaga Amil Zakat. Selebihnya pasal-pasal yang dimohonkan oleh para pemohon ditolak oleh Mahkamah Konstitusi. ${ }^{24}$ Karena keputusan Mahkamah Konstitusi bersifat final dan mengikat,

${ }^{22}$ Adapun lembaga-lembaga zakat yang melakukan permohonan uji materi tersebut adalah Yayasan Dompet Dhu'afa, Yayasan Rumah Zakat Indonesia, Yayasan Yatim Mandiri, Yayasan Portal Infak, Yayasan Dana Sosial Al Falah, Lembaga Pendayagunaan dan Pemberdayaan Zakat, Infak, Sedekah dan Wakaf Harapan Ummat (LPP ZISWAF HARUM), Yayasan Harapan Dhu'afa Banten, Lembaga Manajemen Infak (LMI), YPI Bina Madani Mojokerto, Rudi Dwi Setiyanto dari Gresik, Arif Rahmadi Haryono dari Bekasi, Fadlullah dari Banten dan Sylviani abdul Hamid dari Jakarta. Pemohon mengajukan permohonan pada tanggal 16 Agustus 2012

${ }^{23}$ Mustolih Siradj, Jalan Panjang,... hlm. 424

24 Putusan Mahkamah Konstitusi RI No. 86/PUU-X/2012 tentang Keputusan Uji Materi UU No. 23 Tahun 2011 tentang Pengelolaan Zakat 
maka apapun hasilnya semua pihak berkewajiban untuk menghormati keputusan itu. Dengan demikian UU No. 23 Tahun 2011 tentang Pengelolaan Zakat secara filosofis, yuridis, politis, sosiologis maupun administratif sah dan legal menjadi acuan dalam pengelolaan zakat.

Selain itu berkaitan dengan hubungannya dengan pengelolaan zakat pada perbankan syariah, dalam UU No. 23 Tahun 2011 tentang Pengelolaan Zakat ini tidak disebutkan kata-kata bank syariah baik sebagai lembaga pengelola zakat maupun sebagai lembaga yang diajak bekerja sama dalam pengumpulan zakat. Dalam UU pengelolaan zakat ini hanya menyebutkan lembaga sebagai pengelola zakat hanya BAZNAS dan LAZ. Hilangnya kata bank syariah dalam UU ini menurut Data Inventaris Masalah (DIM) No. 146, pemerintah beranggapan kerjasama antara BAZNAS dengan perbankan terlalu teknis untuk diatur dalam undang-undang. Alasan ini juga menjadi dasar pemerintah melakukan perubahan terhadap pasal 21 ayat 2 dan ayat 3 UU Pengelolaan Zakat, sehingga kerjasama BAZNAS dan LAZ dengan bank menjadi hilang.

Hilangnya kata bank syariah dalam UU pengelolaan zakat ini, menurut pemerintah tidaklah menghilangkan peran bank syariah dalam pengelolaan zakat, karena dalam pasal 7 ayat 2 dibunyikan "Dalam melaksanakan tugas dan fungsinya, BAZNAS dapat bekerjasama dengan pihak terkait sesuai dengan ketentuan peraturan perudang-undangan". Kata "pihak terkait" yang dimaksud dalam pasal 7 ayat 2 kemudian disebutkan dalam penjelasan pasal 7 ayat 2 dimana kata "pihak terkait' yang dimaksud antara lain kementerian, Badan Usaha Milik Negara (BUMN), atau lembaga luar negeri. Mengacu pada penjelasan ini, menurut pemerintah kata bank syariah telah termaktub dalam Badan Usah Milik Negara (BUMN) sehingga tidak perlu diatur secara khusus. ${ }^{25}$

${ }^{25}$ Ahmad Dukhoir, Hukum Zakat..., hlm. 
Meskipun pemerintah telah memberikan penjelasan terkait atas pengesahan UU No. 23 Tahun 2011 tentang Pengelolaan Zakat, namun kritikan terhadap materi-materi yang terdapat dalam UU tersebut masih tetap ada. Terutama menyangkut pengelolaan zakat lewat perbankan syariah yang tidak pernah disinggung dalam UU Pengelolaan Zakat. Tidak disinggungnya perbankan syariah dalam UU pengelolaan zakat ini menunjukkan ketidaksinkronan antara UU Perbankan syariah dengan UU pengelolaan zakat. Hal ini mengingat dalam UU Perbankan Syariah No. 21 tahun 2008 disebutkan dalam pasal 4 ayat 2 bahwa bank syariah dan UUS dapat menjalankan fungsi sosial dalam bentuk lembaga baitul mal, yakni menerima dana yang bersumber dari zakat, infak, sedekah, hibah atau dana sosial lainnya dan menyalurkannya kepada organisasi pengelola zakat. Disebutkannya dapat menjalankan fungsi sosial dalam bentuk lembaga baitul mal, secara tidak langsung telah membolehkan bank syariah bertindak sebagai amil zakat. Bank syariah sebagai amil zakat secara yuridis akan bertentang dengan UU pengelolaan Zakat yang tidak mengakomodir bank syariah sebagai amil zakat.

\section{KESIMPULAN}

Proses menjadikan RUU perbankan syariah dan RUU pengelolaan zakat menjadi UU yang sah dan legal melewati proses yang panjang. Dalam prosesnya terdapat tarik menarik antara yang mendukung pembentukan undang-undang dengan mereka yang tidak sepakat masalah perbankan syariah dan pengelolaan zakat diatur secara formal dalam bentuk undangundang. Memang harus diakui pembentukan undang-undang dipengaruhi oleh tingkat perkembangan masyarakat, tingkat ekonomi, budaya, ilmu pengetahuan dan teknologi, serta kepercayaan agama dalam sebuah masyarakat. Dari 10 fraksi yang ada di DPR RI, 9 fraksi menyatakan persetujuannya RUU 
perbankan syariah dan RUU pengelolaan zakat di sahkan menjadi UU, dan ada 1 fraksi yang menolaknya yakni F-PDS.

Meskipun ada penolakan dari 1 fraksi, namun akhirnya DPR dan Presiden mengesahkan UU perbankan syariah dengan menetapkan UU No. 21 Tahun 2008 tentang Perbankan Syariah pada tanggal 17 Juni 2008 dan pengundangannya oleh Presiden pada tanggal 16 Juli 2008. Berikutnya pemuka Islam dan pemerhati zakat mendesak pemerintah untuk segera melakukan amandemen terhadap UU No. 38 Tahun 1999. Atas desakan itu kemudian dan DPR dan pemerintah mensahkan UU No. 23 Tahun 2011 tentang Pengelolaan Zakat sebagai pengganti UU No. 38 Tahun 1999.

\section{REFERENSI}

Ahmad Dakhoir, Hukum Zakat; Pengaturan Integrasi Kelembagaan Pengelola Zakat Dengan Fungsi Lembaga Perbankan Syariah. Surabaya: Aswaja Presindo, cet. I, 2015

Aristoni, Problematika Peran Perbankan Syariah Dalam Regulasi Kelembagaan Pengelolaan Zakat, Jurnal Ziswaf, Vol. 5, No. 1, Juni 2018

Fatwa MUI No.8 Tahun 2011 tentang Amil Zakat

Indah Purbasari, dkk, Alokasi, Distribusi dan Dana Tanggung Jawab Sosial di Perbankan Syariah dalam Masalahmasalah Hukum, Jilid 44 No.2 April 2015.

Moh. Mahfud MD., Politik Hukum di Indonesia, Jakarta: Rajawali Press, 2009.

Muhammad Amin Summa, Sinergi Fiqih dan Hukum Zakat Dari Zaman Klasik Hingga Kontemporer. Ciputat: Kolam Publising, cet. 1, 2019

Mustolih Siradj, Jalan Panjang Legislasi Syariat Zakat di Indonesia; Studi Terhadap Undang-Undang No. 23 Tahun 2011 tentang Pengelolaan Zakat, Jurnal Bimas Islam, Vol. 7 No. 3 Tahun 2014. 
Nevi Hasnita, Politik Hukum Ekonomi Syariah di Indonesia, Jurnal Hukum Pidana dan Politik Hukum, Legitimasi, vol. 1, No.2, Januari-Juni 2012

Nikmatul Masruroh, Zakat di Perbankan Syariah, Jurnal alMashraf, Vol.2, No.1 Oktober 2015.

Nurnasrina dan P. Adiyes Putra, Kegiatan Usaha Bank Syariah, Jogyakarta: Kalimedia, Cet.2, 2017

Otoritas Jasa Keuangan (OJK) RI, Statistik Perbankan Syariah, Mei 2019,

Soerjono Soekanto dan Sri Mamudji, Penelitian Hukum Normatif

Suatu Tinjauan Singkat, Jakarta: Raja Grafindo Persada, cet. Ke-11

Putusan Mahkamah Konstitusi RI No. 86/PUU-X/2012 tentang

Keputusan Uji Materi UU No. 23 Tahun 2011 tentang Pengelolaan Zakat

UU No. 38 Tahun 1999 tentang Pengelolaan Zakat

UU No. 21 Tahun 2008 tentang Perbankan Syariah

UU No. 23 Tahun 2011 tentang Pengelolaan Zakat 